\title{
Coastal salmon farms attract large and persistent aggregations of wild fish: an ecosystem effect
}

\author{
T. Dempster ${ }^{1,2, *}$, I. Uglem ${ }^{3}$, P. Sanchez-Jerez ${ }^{4}$, D. Fernandez-Jover ${ }^{4}$, \\ J. Bayle-Sempere ${ }^{4}$, R. Nilsen ${ }^{5}$, P. A. Bjørn ${ }^{5}$ \\ ${ }^{1}$ SINTEF Fisheries and Aquaculture, 7465 Trondheim, Norway \\ ${ }^{2}$ Department of Zoology, University of Melbourne, Victoria 3010, Australia \\ ${ }^{3}$ Norwegian Institute for Nature Research, 7485 Trondheim, Norway \\ ${ }^{4}$ Department of Marine Sciences and Applied Biology, University of Alicante, PO Box 99, 03080 Alicante, Spain \\ ${ }^{5}$ NOFIMA, 9192 Tromsø, Norway
}

\begin{abstract}
Coastal aquaculture is a globally expanding enterprise. Currently, 1200 salmon farms operate in coastal Norway, yet their capacity to aggregate and subsequently modify wild fish distributions is poorly known. Aggregations of wild fish at 9 farms and 9 control locations were counted on 3 separate days in June to August 2007. On each sampling occasion, 6 counts were made at 5 distinct depth-strata at each farm and control location. Wild fish were 1 to 3 orders of magnitude more abundant at farms than at control sites, depending on the location. Gadoid fish (Pollachius virens, Gadus morhua and Melanogrammus aeglefinus) dominated farm-associated assemblages and were present across a wide range of sizes, from juveniles to large adults. Estimated total farmaggregated wild fish biomass averaged 10.2 metric tonnes (t) per farm across the 9 farms (range: $600 \mathrm{~kg}$ to $41.6 \mathrm{t}$ ). Applied across the geographical range of Norway's 1200 salmon farms, our estimates indicate that salmon farms attract and aggregate over $12000 \mathrm{t}$ of wild fish into a total of just 750 ha of coastal waters on any given day in summer. Possible consequences of these persistent, substantial aggregations of wild fishes at farms include a heightened potential for the transfer of pathogens from salmon farms to wild fish and among adjacent salmon farms, and altered availability of wild fish to fisheries. Restrictions on fishing in the immediate surrounds of salmon farms may avoid farms acting as ecological traps, particularly for species with depressed populations such as G. morhua, which are highly attracted to farms.
\end{abstract}

KEY WORDS: Anthropogenic perturbation - Aquaculture -Sea-cage · Wild fish · Attraction · Salmo salar · Pollachius virens - Gadus morhua

Resale or republication not permitted without written consent of the publisher

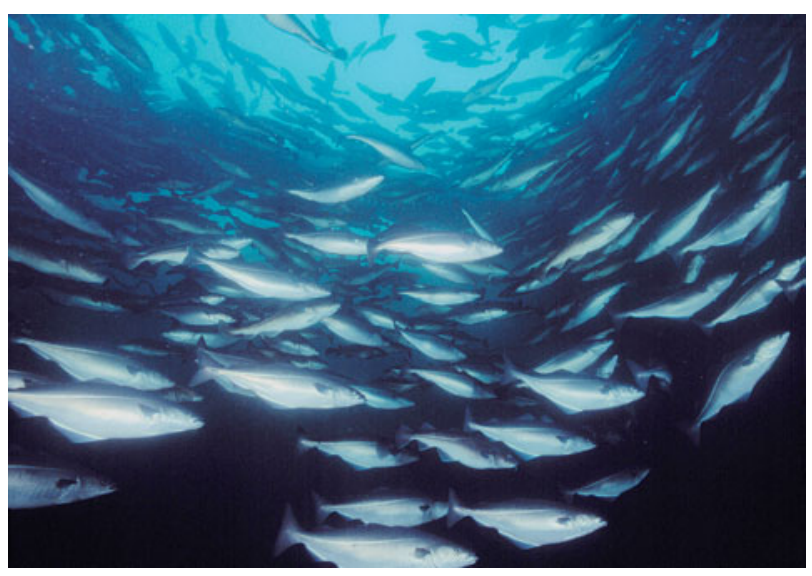

Wild fish such as saithe Pollachius virens aggregate in large numbers around Norwegian salmon farms.

Image: Per Eide

\section{INTRODUCTION}

Anthropogenic perturbations in coastal marine ecosystems manifest in a variety of different forms, including the introduction of nutrients and pollutants, the physical modification of habitats, and alterations to populations of wild species through fishing and other processes. Salmonid farms are now common artificial elements in cold temperate coastal ecosystems, producing over 1.5 million $t$ of fish annually (FAO 2008) across thousands of sites. Norway alone produced $689000 \mathrm{t}$ of salmonids in 1198 coastal farms in 2007 (Norwegian Fisheries Directorate 2008). Salmonid farm- 
ing precipitates ecological changes in coastal ecosystems by increasing nutrient inputs, modifying benthic communities, and by affecting wild salmonid populations through escapes of farmed fish and increased sea-lice infections (review: Weir \& Grant 2005). While numerous studies have investigated the effects of salmon farming on wild salmonids, scant attention has been paid to the ecological effects of farms on nonsalmonid wild fish species.

Although wild fish are present in the vicinity of salmon farms (Carss 1990), no study has estimated the magnitude of these assemblages. Analogous structures to sea-cage salmonid farms in cold temperate waters are warm temperate and sub-tropical farms containing sea bream and sea bass. Diverse aggregations of up to $40 \mathrm{t}$ of wild fish occur around these farms (e.g. Mediterranean Sea: Dempster et al. 2004; Canary Islands: Tuya et al. 2006). These aggregations are temporally stable for weeks to months and are composed of a high proportion of adults (Dempster et al. 2002, 2005). Lost feed is primarily responsible for attracting wild fish to the cages (Tuya et al. 2006). Aggregation results in a marked dietary shift away from natural foods towards waste feed for the dominant farm-aggregated species (Fernandez-Jover et al. 2007a, 2008). The dietary shift in turn leads to increased condition, higher body fat concentration, and modified $\omega 3: \omega 6$ fatty acid composition of body tissue, which changes to mirror the composition of lost feed (Fernandez-Jover et al. 2007a). Residence in the vicinity of farms by wild fish may also lead to consumption of feed-based pharmaceuticals or increased bio-accumulation of heavy metals (deBruyn et al. 2006).

Aggregation of wild fish adjacent to caged fish may also increase the risk of transfer of shared pathogens between the 2 groups (Diamant et al. 2007, Uglem et al. 2008) or, possibly, to nearby fish farms if wild fish migrate between farms (Uglem et al. 2009). The concentration of wild fish at fish farms may assist in nutrient dispersal at farming sites (Vita et al. 2004) and could also increase the vulnerability of fish to capture, which has led to the proposed implementation of nofishing zones around sea-cage farms (Dempster et al. 2006). Documenting the magnitude, composition and variability of wild fish aggregations at salmon farms is a key step to determining the scale and importance of their ecological effects on cold temperate wild fish populations.

In the present study, we sought to determine the extent to which wild fish from surrounding waters aggregate around salmon farms across the farming regions in Norway. Specifically, we tested the hypotheses that: (1) wild fish abundances would be greater at farms than at control locations; (2) aggregation composition and aggregated fish sizes would vary among farms on a Norway-wide scale; and (3) aggregation composition at farms would vary with depth.

\section{MATERIALS AND METHODS}

Video-based estimates of fish assemblage diversity and abundance. Previous counts of wild fish around fish farms have been conducted around relatively shallow farms (20 to $40 \mathrm{~m}$ depth) in the Mediterranean and Canary Islands using either pelagic (Dempster et al. 2002) or benthic (Tuya et al. 2006) diver-based techniques. As farms in Norwegian fjord systems are typically moored in waters beyond diver depths, we used an underwater video camera system capable of recording in the water column and on the bottom to depths of $150 \mathrm{~m}$. The camera-rig consisted of a black and white 1/3' Sony EXview HAD CCD camera contained within a half-spherical housing (Lamberg Bio-Marin). Four monochromatic amber LED lights $(2 \mathrm{~W})$ were mounted above the camera to provide evenly dispersed lighting. The camera was controlled from the surface by a single $9 \mathrm{~mm}$ polyurethane/Kevlar cable and recordings were made on a Sony mini-DV recorder. Lights were left on during all counts to avoid potential biases in the responses of fish towards them.

Since visibilities varied between the different depthstrata, we designed a technique that would be robust for comparisons of counts at a range of depths. We used stationary timed counts with the camera slowly revolving $360^{\circ}$ within the housing. For each count, a 1 min recording was made which consisted of 2 complete revolutions (30 s) of the camera. In the water column, fish were counted in a cylindrical volume that varied with depth due to varying visibilities. Count volumes within which fish were identifiable varied from $387 \mathrm{~m}^{3}$ at depths $>80 \mathrm{~m} \mathrm{(4} \mathrm{m}$ height by $5 \mathrm{~m}$ distance from the camera), to $707 \mathrm{~m}^{3}$ at depths of $<80 \mathrm{~m} \mathrm{(4 \textrm {m }}$ height by $7.5 \mathrm{~m}$ distance from the camera), based on preliminary work with objects at known distances. Bottom counts included the water column to $1 \mathrm{~m}$ above the substrate, with volumes varying from $79 \mathrm{~m}^{3}$ at depths of $>80 \mathrm{~m} \mathrm{(5} \mathrm{m} \mathrm{distance} \mathrm{from} \mathrm{the} \mathrm{camera),} \mathrm{and} 177 \mathrm{~m}^{3}$ at depths $<80 \mathrm{~m}$ (7.5 m distance from the camera). For each 1 min recording, individuals of all species present were counted separately for the two $30 \mathrm{~s}$ revolutions of the camera. The maximum abundance observed in either of the 2 revolutions was used, as is typical in baited remote underwater video (BRUV) studies (e.g. Heagney et al. 2007).

Visual estimates of fish populations are subject to method specific biases and limitations, invariably underestimating fish numbers and underestimating or overestimating fish species that react negatively or positively to the count equipment (Harmelin-Vivien 1985). 
However, potential biases of the technique should have been consistent among the different sampling depths and locations.

Spatial and temporal variability of wild fish assemblages around salmon farms. To determine the variability of wild fish aggregation composition and abundance, wild fish were counted at 9 salmon farms and 9 control locations in 3 fish farming regions (Ryfylke, Hitra and Øksfjord) throughout Norway (Table 1 \& Fig. 1). In each region, 2 of the 3 farms contained salmon $>1 \mathrm{~kg}$ in weight, with the third farm containing smolts of $<500 \mathrm{~g}$. Control areas of similar depth and bottom habitat were located in 1 to $2 \mathrm{~km}$ distance from the salmon farms.

Video sampling at each farm and control location was conducted on 3 random days during summer 2007. Six replicate camera drops were made per sampling day with 5 distinct depth-strata (surface: $5 \mathrm{~m}$ water depth; cage; $20 \mathrm{~m}$ water depth; mid-water; $5 \mathrm{~m}$ above bottom; bottom) sampled during each camera drop. A total of 1620 separate video counts were made. At each sampling location, one vertical temperature profile was taken with a Tidbit temperature tag attached to the camera rig. Minimum and maximum water temperatures varied among regions and with depth (Ryfylke: 6.0 to $16.5^{\circ} \mathrm{C}_{\text {; Hitra: }} 7.0$ to $16.5^{\circ} \mathrm{C}_{\text {; }} \varnothing \mathrm{ksfjord}$ : 4.5 to $11.5^{\circ} \mathrm{C}$ ), but vertical profiles were relatively consistent among farm and control locations within the 3 regions studied.

Size structure of the dominant farm-associated species. Collections of the 4 most abundant farmassociated wild fish species were made in the 3 study regions to determine the size structure of the aggregated wild fish assemblages and enable farm-specific estimates of total aggregated biomass. Saithe Pollachius virens ( $\mathrm{n}=323$; captured at 9 farms), Atlantic cod Gadus morhua (n = 168, 8 farms), Atlantic mackerel Scomber scombrus ( $\mathrm{n}=106,5$ farms), and haddock (Melanogrammus aeglefinus ( $\mathrm{n}=48,8$ farms) were captured from immediately beneath the sea-cages with standardized hook-and-line fishing gear on days when camera sampling was conducted. All wild fish were measured (fork length. FL) and weighed to the nearest $5 \mathrm{~g}$.

Estimates of total aggregated wild fish abundances and biomass at farms. Video counts were scaled up to estimate total abundance and biomass at each farm using a modification of the method of Dempster et al. (2004). The attractive volume of each farm to wild fish was defined as the area enclosed by the cages plus $5 \mathrm{~m}$ around the cages and multiplied by the average farm depth (Table 1). The mean abundance per $500 \mathrm{~m}^{3}$ on the 3 sampling occasions at each farm and for each depth stratum was multiplied by the total number of $500 \mathrm{~m}^{3}$ counts possible in each specific depth stratum. Surface counts (made at $5 \mathrm{~m}$ water depth) were deemed representative for depths of 0 to $10 \mathrm{~m}$, cage counts (made at $20 \mathrm{~m}$ ) covered depths of 10 to $30 \mathrm{~m}$, midwater counts covered the water column from $30 \mathrm{~m}$ to $10 \mathrm{~m}$ above the bottom, $5 \mathrm{~m}$ above bottom counts covered the water column from 1 to $10 \mathrm{~m}$ above the bottom, and bottom counts were limited to the waters 0 to $1 \mathrm{~m}$ above the bottom. For the surface and cage counts, the volume occupied by cages containing salmon was subtracted from the available volume. The scaled-up estimates from the 5 different depth strata were combined to estimate the total number of each species at a farm. Average sizes of the dominant species at each of the 9 farms were then used to convert total numbers of each species to biomass estimations. Where insufficient numbers of a species were captured at any particular farm, we used the combined mean weight for this species across all farms.

Table 1. Characteristics of fish farms in intensive fish farming regions (Ryfylke, Hitra and Øksfjord) in Norway. Volume $=$ total farm volume - volume of the cages enclosing salmon, according to the procedure described in 'Materials and methods'. \% rocky bottom: percentage of video counts conducted on rocky substrates at each farm

\begin{tabular}{|c|c|c|c|c|c|c|c|}
\hline Farm no. & $\begin{array}{l}\text { Area } \\
\left(\mathrm{m}^{2}\right)\end{array}$ & $\begin{array}{l}\text { Depth } \\
\text { (m) }\end{array}$ & $\begin{array}{l}\text { Volume } \\
\left(\mathrm{m}^{3}\right)\end{array}$ & No. of cages & $\%$ rocky bottom & $\begin{array}{l}\text { Salmon } \\
\text { weight }\end{array}$ & $\begin{array}{c}\text { Approx. total salmon } \\
\text { biomass (t) }\end{array}$ \\
\hline \multicolumn{8}{|l|}{ Ryfylke } \\
\hline 1 & 6750 & 100 & 603000 & 16 & 17 & $>1 \mathrm{~kg}$ & 3000 \\
\hline 2 & 8225 & 110 & 792250 & 9 & 28 & post-smolts & 100 \\
\hline 3 & 4050 & 65 & 227520 & 10 & 22 & $>1 \mathrm{~kg}$ & 1000 \\
\hline \multicolumn{8}{|l|}{ Hitra } \\
\hline 4 & 8575 & 50 & 341250 & 7 & 44 & post-smolts & 100 \\
\hline 5 & 6750 & 60 & 333000 & 16 & 50 & $>1 \mathrm{~kg}$ & 2000 \\
\hline 6 & 6750 & 90 & 535500 & 16 & 0 & $>1 \mathrm{~kg}$ & 3000 \\
\hline \multicolumn{8}{|l|}{ Øksfjord } \\
\hline 7 & 4950 & 80 & 342000 & 12 & 33 & post-smolts & 100 \\
\hline 8 & 7500 & 70 & 375000 & 12 & 78 & $>1 \mathrm{~kg}$ & 2000 \\
\hline 9 & 4950 & 80 & 342000 & 12 & 39 & $>1 \mathrm{~kg}$ & 2000 \\
\hline
\end{tabular}


While a greater attractive farm volume, covering a wider area around farms, might have better accounted for mobile fish species, only the area immediately beneath the cages plus $5 \mathrm{~m}$ around the farm was used in our analysis. In all cases, the attractive farm area was less than 1 ha (0.33 to 0.8 ha; Table 1$)$. While farmassociated wild fish do occur at distances greater than $5 \mathrm{~m}$ from the cages, densities are greatest immediately beneath salmon farms and rapidly decline at distances of 10 s to 100 s of metres away (Dempster et al. unpubl. data; July and October 2006). The estimates obtained by the method used in the present study should therefore be regarded as conservative minimum estimates of farm-associated aggregations.

Univariate statistical analyses. The analysis of variance (ANOVA) design for comparisons among farms and control locations had the factors Farm/Control (fixed), Region (fixed), Depth (fixed), Locations (random and nested within Farm/Control and Region), and Time (random and nested within Farm/Control, Region and Location). Prior to ANOVA, heterogeneity of variance was tested with Cochran's $C$-test. Data were $\ln (x+1)$ transformed if variances were significantly different at $p=0.05$. As ANOVA is robust to heterogeneity of variances, particularly for large balanced experiments (Underwood 1997), ANOVAs were performed and $\mathrm{p}$ was set at 0.01 when variances remained heterogeneous even after transformation. Post-hoc Student-

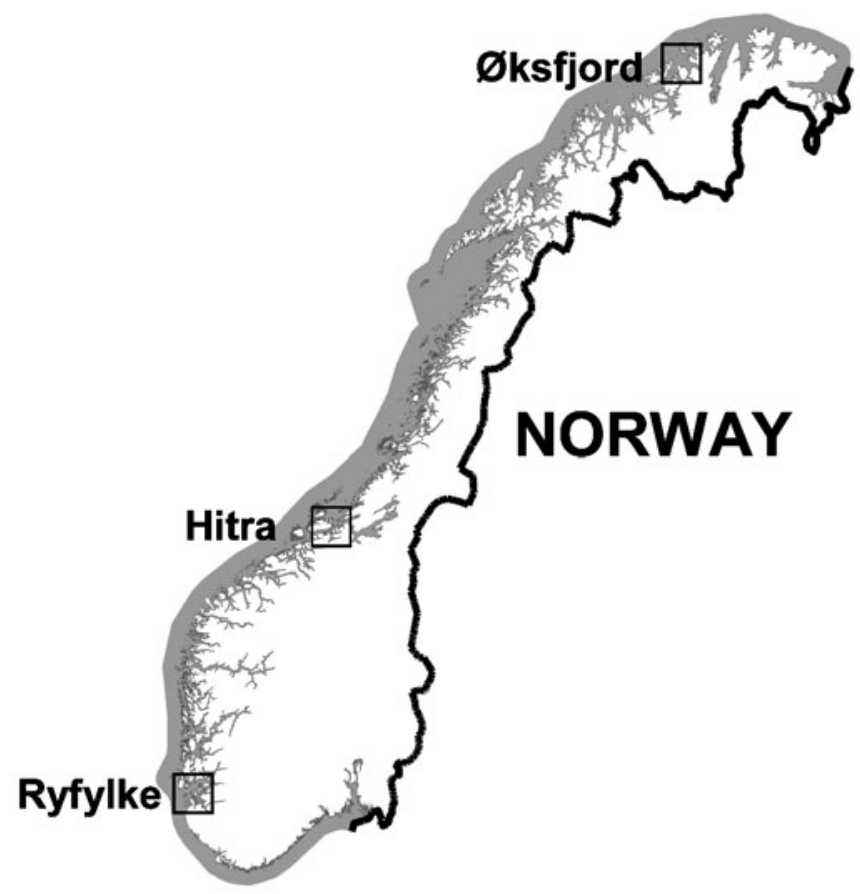

Fig. 1. Farm and control locations (1 to 9) sampled in the 3 Norwegian salmon farming regions of Ryfylke, Hitra and Øksfjord
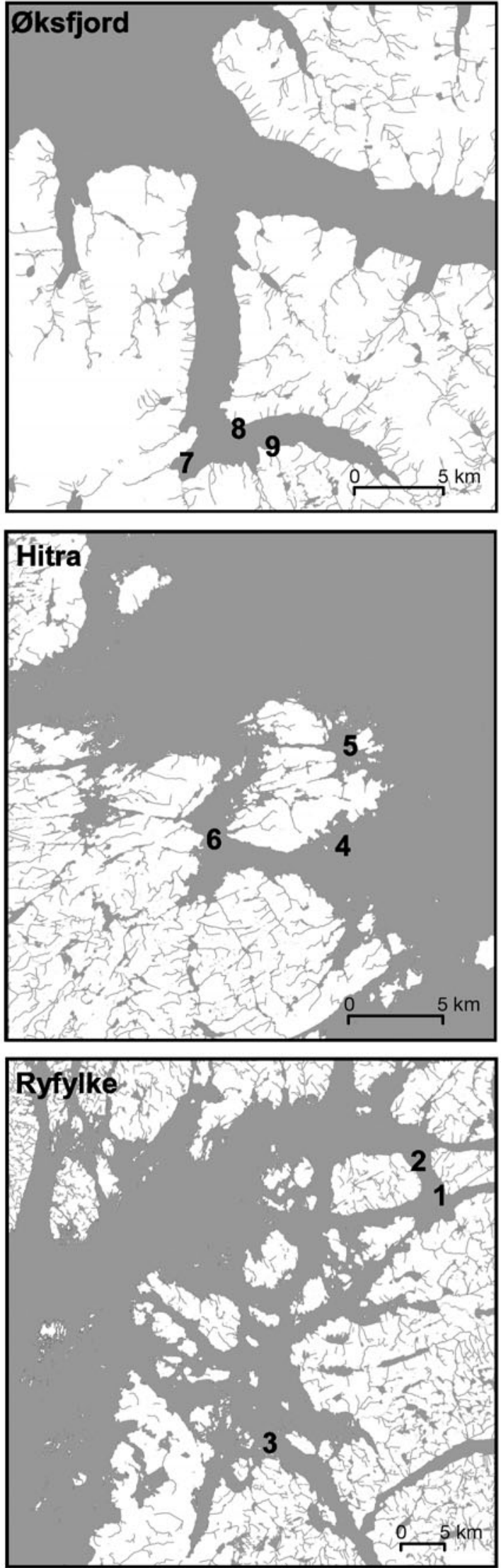
Newman-Keuls (SNK) tests were used to determine significant differences among treatments.

Assemblage analysis. Non-parametric multivariate techniques were used to compare assemblages among farm and control locations and among the sampling times at farm locations. All multivariate analyses were performed using the PRIMER statistical package. Prior to calculating the Bray-Curtis similarity matrices, the data were pooled by summing the 90 counts for each location or the 30 counts for the 3 sampling occasions at each farm to reduce the stress of MDS representation. Fourth-root transformations were performed to even out the contributions of common and rare species in the similarity matrix, and presence/absence transformations were conducted to assess differences based on species composition alone. Non-metric multidimensional scaling (nMDS) was used as the ordination method. Variables that had more influence on similarities within groups and dissimilarities among groups of locations or depths, determined by ANOSIM (analysis of similarity), were calculated using the SIMPER (similarity percentages) procedure. The ANOSIM permutation test was used to assess the significance of differences among farm and control locations.

Relationships between salmon farm characteristics and wild fish aggregations. Linear regressions were used to test for patterns that may have explained variability in the total aggregated biomass among farms. Attractive farm area, farm depth and stocked salmon biomass (Table 1) were regressed against total farmaggregated biomass estimates for Pollachius virens, Gadus morhua and Melanogrammus aeglefinus. In addition, we performed a separate one-way ANOVA on the abundances in bottom counts made beneath farms to determine whether rocky bottom habitats resulted in greater abundances of $P$. virens, $G$. morhua and $M$. aeglefinus than sand or mud bottom habitats. Bottom habitats were categorized as rocky $(n=55)$ or sand/mud $(n=107)$ during each of the bottom counts.

\section{RESULTS}

\section{Wild fish assemblage composition at farm and control locations}

Fifteen species were observed at the farm and control locations (Table 2). The most common families observed at both farm and control locations were Gadidae (6 species) and Lotidae (2 species). Overall, more species were observed at Ryfylke (13 species; $\left.59^{\circ} \mathrm{N}\right)$ than at Hitra (8 species; $63^{\circ} \mathrm{N}$ ) and Øksfjord (9 species; $70^{\circ} \mathrm{N}$ ). Bottom counts (12 species) were more diverse than counts in the water column (4 to 6 species). Pollachius virens and Gadus morhua were the only species observed in all depth strata. Eight species were restricted to the bottom or immediately above the bottom while 3 predominantly planktivorous species (Scomber scombrus, Trachurus trachurus, and Clupea harengus) were only observed in counts from the midwater to the surface.

The 2-dimensional nMDS plot (Fig. 2) based on abundances of species revealed a clear separation of farm-associated and control wild fish assemblages. ANOSIM conducted on 4th-root transformed data indicated that wild fish assemblages at farms were significantly different from assemblages at control locations (Global $\mathrm{R}=0.234, \mathrm{p}=0.007$ ). ANOSIM performed on

Table 2. Wild fish species observed in video counts in specific depth-strata (+) and at farm and control locations ( $\square) .{ }^{*}$ Indicates species that were significantly more abundant at farm than at control locations. Depth-strata are B: bottom; A: $5 \mathrm{~m}$ above bottom; M: mid-water; Ca: cage (20 m water depth), S: surface (5 m water depth)

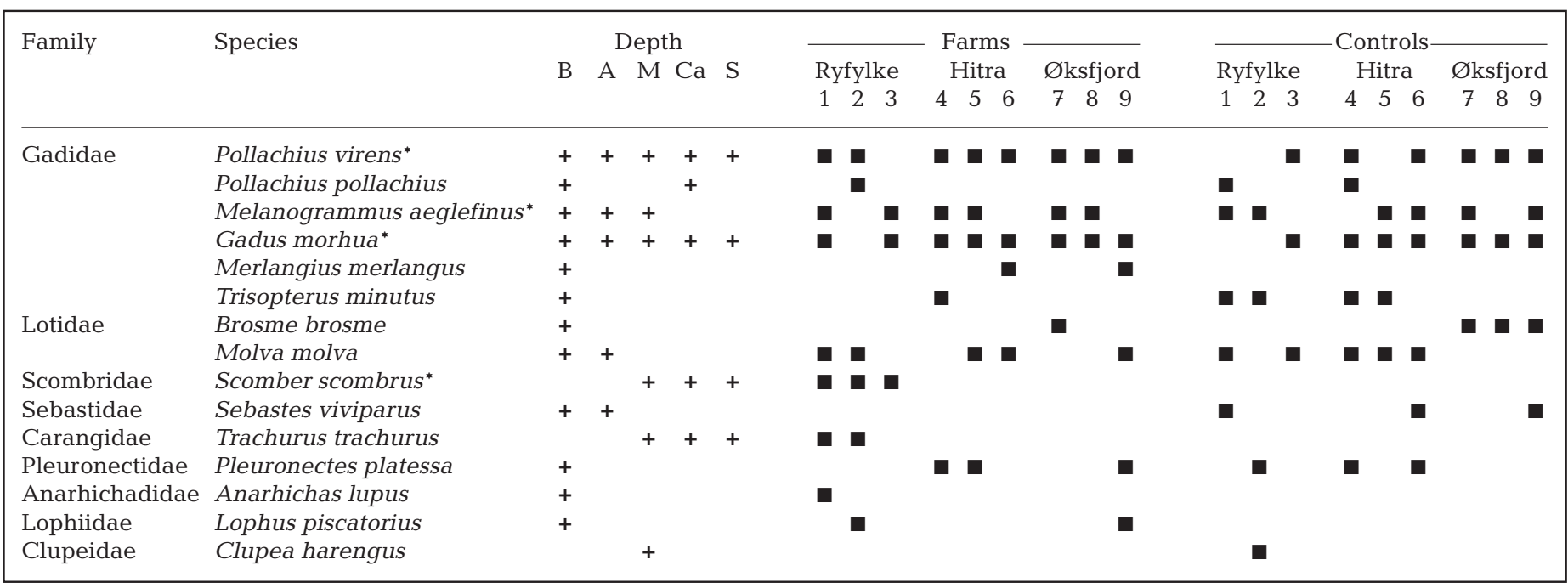



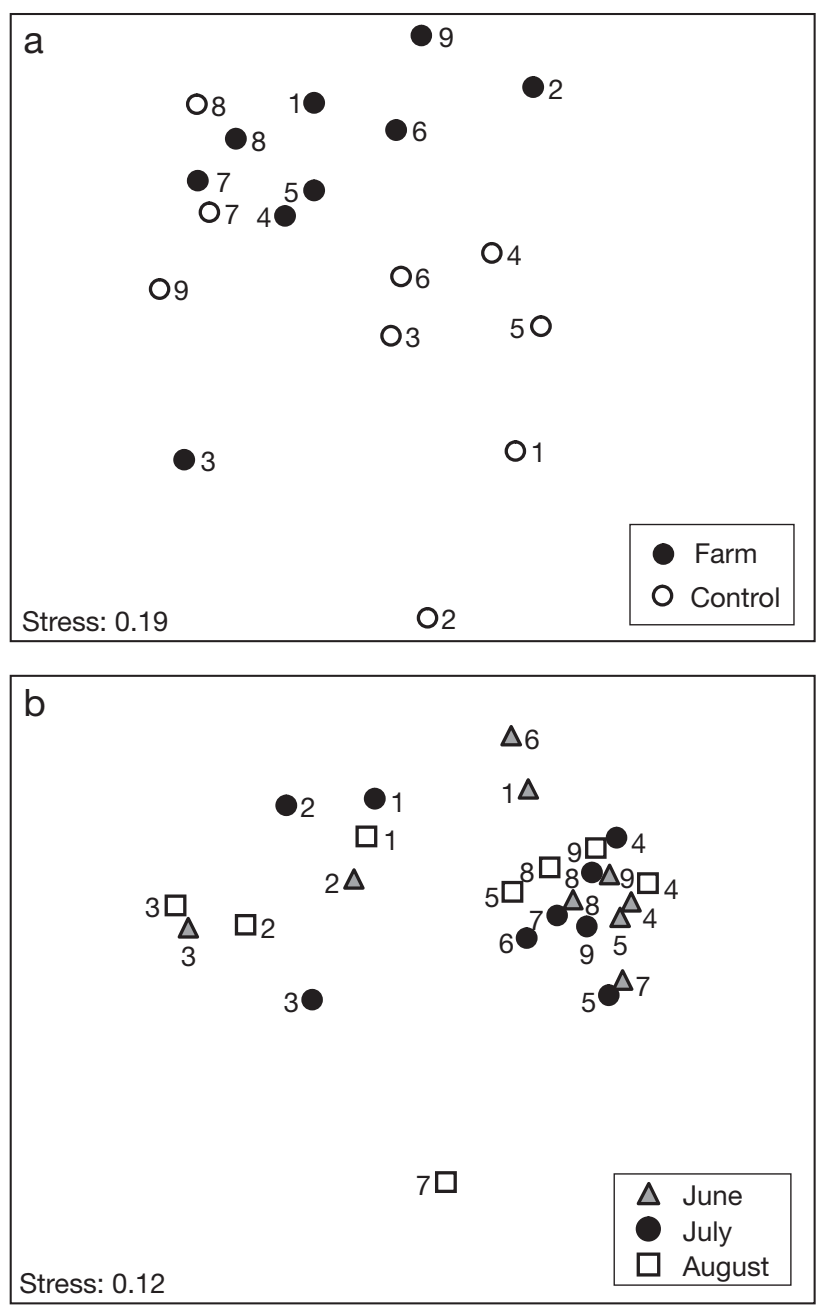

Fig. 2. Non-metric multi-dimensional scaling plot of (a) wild fish aggregations at farm and control sites throughout Norway and (b) wild fish aggregation variability at farms among the 3 sampling times (June, July and August). Farms and controls: Ryfylke: 1-3, Hitra: 4-6, Øksfjord: 7-9

presence/absence transformed data revealed no significant difference among farm and control locations (Global $\mathrm{R}=0.06, \mathrm{p}=0.17$ ), indicating that differences in the magnitude of abundances drove the original result rather than differences in species composition. SIMPER analysis of the contributions of individual species to the similarity of assemblages at farm and control locations using the 4th-root transformed data indicated that they were characterised by similar abundances of relatively few taxa. Farm-associated assemblages were characterised by 4 species (Pollachius virens, Gadus morhua, Melanogrammus aeglefinus and Scomber scombrus), which accounted for $90 \%$ of the cumulative similarity $(44,25,13$ and $7 \%$ respectively). Farm 3 was most dissimilar to all other farms as no $P$. virens were observed in video counts there (Fig. 2). Control locations were characterized by abundances of 5 spe- cies (G. morhua, P. virens, M. aeglefinus, Molva molva and Trisopterus minutus), which accounted for $90 \%$ of the cumulative similarity $(24,24,16,16$ and $8 \%$ respectively). Dissimilarities between the farm and control groups were principally due to abundances of P. virens $(21 \%)$, G. morhua $(12 \%)$, M. aeglefinus $(12 \%)$, S. scombrus $(10 \%)$ and Pleuronectes platessa $(7 \%)$, which were more abundant at farms, and T. minutus ( $8 \%)$, M. molva (7\%), and Brosme brosme (6\%), which were more abundant at control locations. Controls 7, 8 and 9 grouped closest to farm assemblages due to the abundant $P$. virens observed in bottom counts at these locations (Fig. 2).

\section{Differences in abundance among farm and control locations related to regions and depth strata}

The 5-factor ANOVA produced a significant interaction at the lowest level of the analysis for the term Depth $\times$ Time $(\mathrm{F} / \mathrm{C} \times$ Region $\times$ Location) for total abundance, indicating that differences between farm and control locations depended on Region, Location, Depth and Time (Table $3 \&$ Fig. 3). Post-hoc SNK tests revealed that fish were significantly more abundant in the surface and cage depth-strata than at all other depths. At Hitra, total abundances of wild fish at farms were greater than at control sites for all depths, locations and times. Significant variability in total abundances was evident among farms within regions, with Farm $1>2$ and 3 at Ryfylke, Farm $4>5$ and 6 at Hitra and Farms 8 and $9>7$ in Øksfjord (Fig. 3), indicating that some farms attracted far greater numbers of fish in these regions despite their relative proximity.

Differences in the abundances of Pollachius virens at farm and control locations were also dependent on Region, Location, Depth and Time, as indicated by the significant Depth $\times$ Time $(\mathrm{F} / \mathrm{C} \times$ Region $\times$ Location $)$ interaction term (Table 3; Fig. 4a). At Hitra, abundances at farms were significantly greater than at control sites, regardless of depths, locations and times, while farm vs. control differences at Ryfylke and Øksfjord were dependent upon these factors. Large aggregations of $P$. virens, averaging over 20 ind. $500 \mathrm{~m}^{-3}$ in particular depth strata, were observed at 5 of the 9 farms, with greatest abundances occurring in any of the surface, mid-water, $5 \mathrm{~m}$ above bottom or bottom depth strata, depending on the farm.

In general, Gadus morhua (Fig. 4b) and Melanogrammus aeglefinus (Fig. 4c) were significantly more abundant in the bottom and $5 \mathrm{~m}$ above bottom strata at both farms and controls across the 3 regions. For both species, the bottom or $5 \mathrm{~m}$ above bottom counts revealed significantly higher abundances than the corresponding water column counts for both farm and con- 


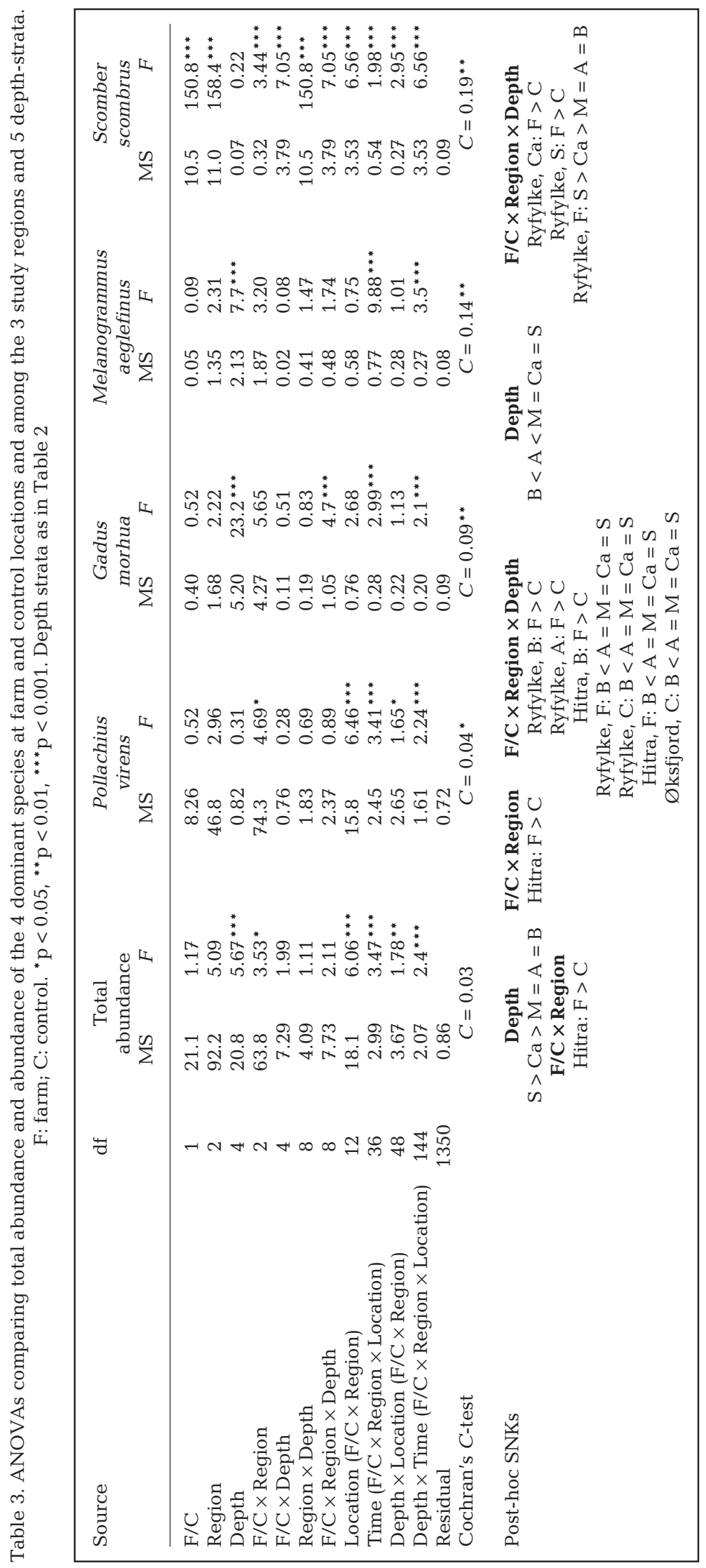

trol locations, and significant differences between farm and control locations were only detected in these 2 depth strata. $G$. morhua had abundances of 2 to 4 ind. $500 \mathrm{~m}^{-3}$ in the bottom depth-strata at 6 farms, while $M$. aeglefinus were most abundant with 2 to 6 ind. $500 \mathrm{~m}^{-3}$ in the bottom or $5 \mathrm{~m}$ above bottom depth strata at 4 farms. For Scomber scombrus, few individuals were recorded at Hitra and none were observed at Øksfjord (Fig. 4d). Within the Ryfylke region, where they occurred in abundances of $>10$ ind. $500 \mathrm{~m}^{-3}$ in particular depth strata at all 3 farms, significantly greater numbers of fish occurred at farms than at control sites in the surface and cage depth strata.

\section{Size structure of the dominant species aggregated at farms}

Sizes and weights of the dominant species captured at farms indicated that wild fish were present across a broad range of size classes (Fig. 5). The 3 gadoid species Pollachius virens, Gadus morhua and Melanogrammus aeglefinus were captured at farms in all 3 regions and ranged in size from small juveniles to large adult fish of up to $12.5,18$ and $4.5 \mathrm{~kg}$, respectively. Significant differences existed in the weights of aggregated $P$. virens among farms (1-way ANOVA, $\left.F_{7,344}=4.1, \mathrm{p}<0.001\right)$, with $P$. virens at Farm 1, Farm 2, Farm 4 and Farm 7 (mean weights 1.5 to $1.7 \mathrm{~kg}$; Fig. 5a-c) significantly greater than at Farm 6 (0.7 kg; Fig. 5b) Similarly, G. morhua varied significantly in size among farms $\left(F_{4,162}=6.6\right.$, $\mathrm{p}<$ 0.001), with small average-sized fish captured at Farm 5 (mean $1.4 \mathrm{~kg}$ ) compared to Farm 4 (3.4 kg) and Farm 8 (4.5 kg; Fig. 5d,e). Insufficient numbers of $M$. aeglefinus were captured to enable comparisons among farms; however, they were present at 8 of the 9 farms, with FL ranging from 33 to $72 \mathrm{~cm}$ and weights ranging from 0.44 to $4.5 \mathrm{~kg}$. Scomber scombrus were sampled from a total of 5 farms at Ryfylke and Hitra. Of the 3 farms where sufficient individuals were captured to enable comparison, fish at Farm $6(0.52 \mathrm{~kg})$ were significantly larger than those sampled from Farm $2(0.37 \mathrm{~kg})$ and Farm $3\left(0.41 \mathrm{~kg} ; F_{2,92}=\right.$ $7.7, \mathrm{p}=0.001)$. 
Ryfylke

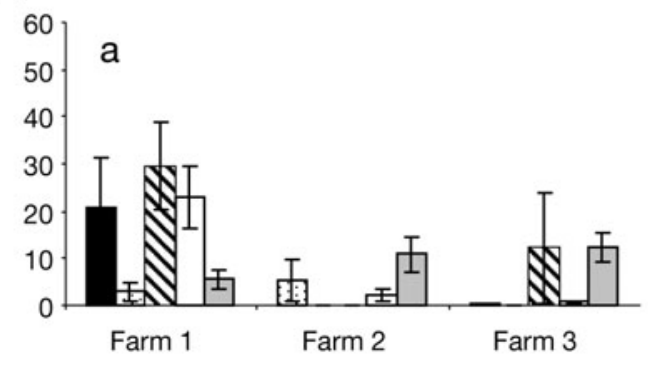

Hitra

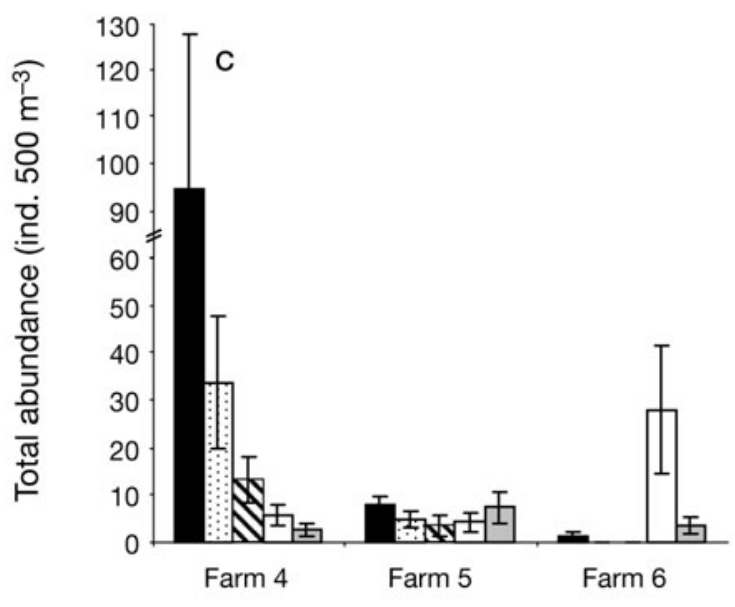

Øksfjord

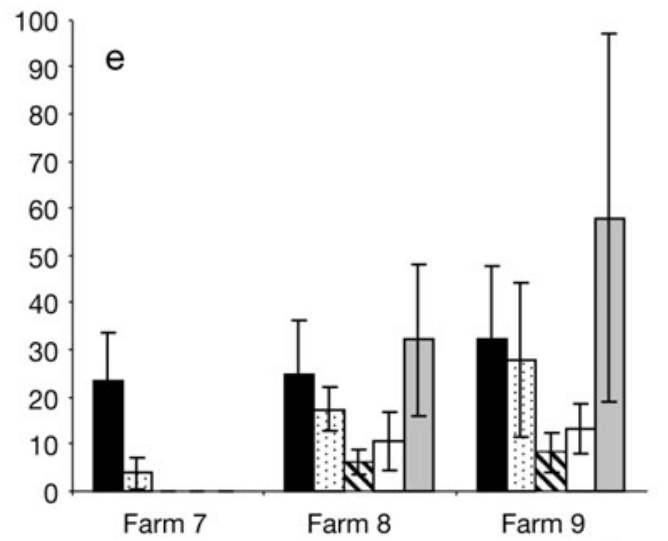

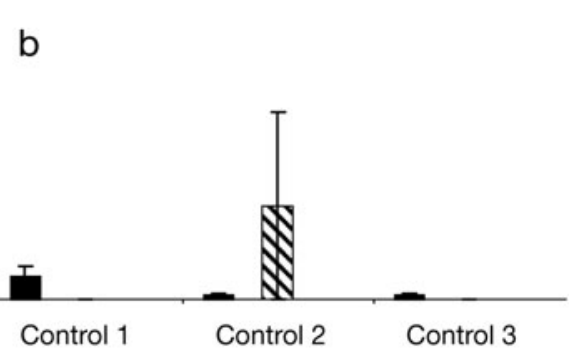

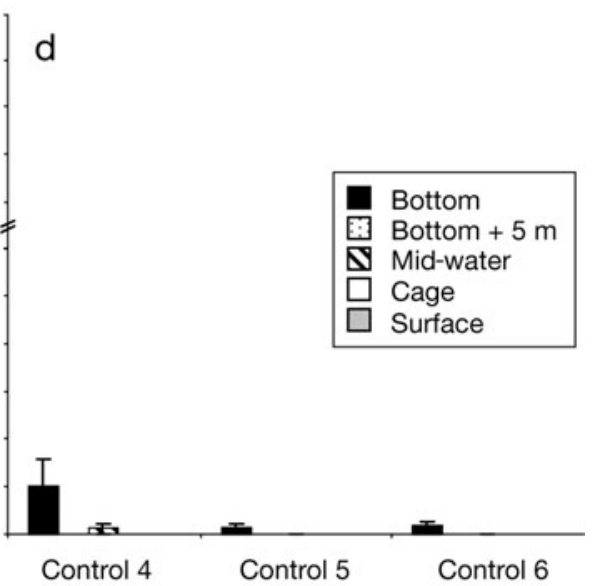

\section{Location}

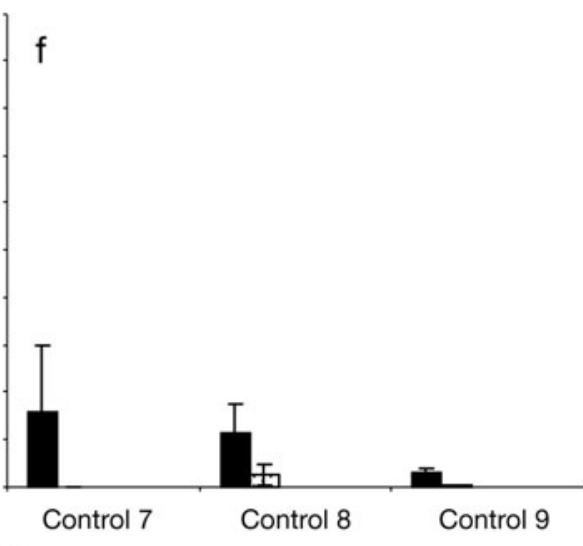

Fig. 3. Total abundances of wild fish per $500 \mathrm{~m}^{3}$ count volume by depth strata for the farm and control locations in each of the 3 intensive fish farming regions. Each bar gives the mean $\pm \mathrm{SE}$ of 18 video counts

\section{Estimates of total farm-associated wild fish biomass for the 4 dominant species}

Abundance estimates from the video counts were scaled up to the total attractive area of the farm (Table 1) and converted to biomasses using the farmspecific average weights for each species. Across all 9 farms, the combined farm-aggregated biomasses of the 4 dominant species (Pollachius virens, Gadus morhua, Melanogrammus aeglefinus, and Scomber scombrus) averaged $10.2 \mathrm{t} \mathrm{farm}^{-1}$. Maximum total aggregated biomass occurred at Farm 1 (41.6 t). Four farms had intermediate total biomasses (6.8 to $14.5 \mathrm{t}$ ), while 4 farms had smaller aggregated biomasses (0.6 to 2.3 t; Fig. 6). Across all 9 farms, P. virens, G. morhua, $M$. aeglefinus and $S$. scombrus comprised 92, $2.4,1.8$ and $3.5 \%$ of the aggregated biomass, respectively. $P$. virens contributed over $80 \%$ of the aggre- 


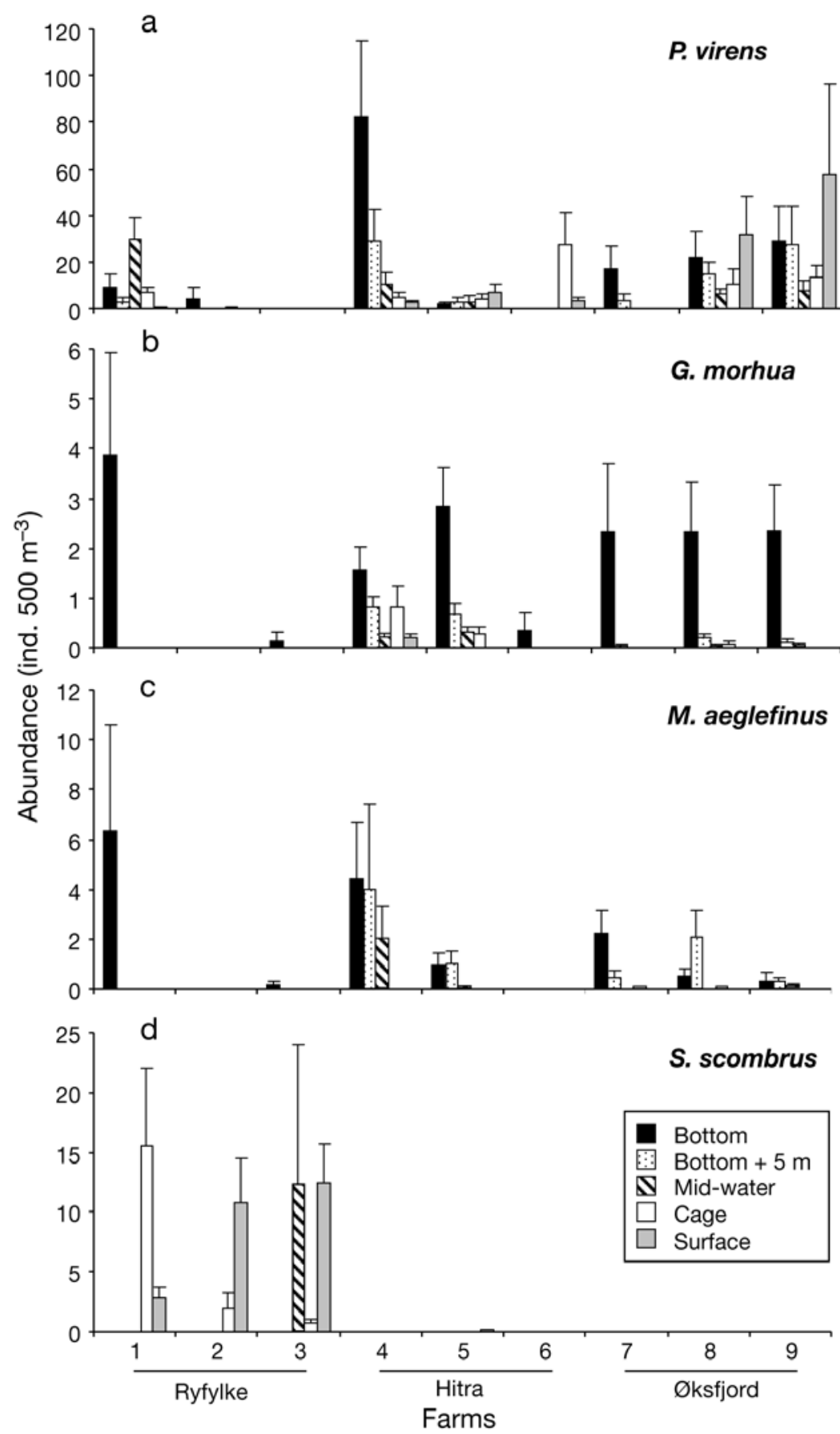

Fig. 4. Abundances of (a) Pollachius virens, (b) Gadus morhua, (c) Melanogrammus aeglefinus and (d) Scomber scombrus ind. $500 \mathrm{~m}^{-3}$ count volume by depth strata for the farm locations in each of the 3 intensive fish farming regions. Each bar gives the mean $\pm \mathrm{SE}$ of 18 video counts

\section{Relationships between abundance and bio- mass of wild fish and farm characteristics}

Gadus morhua were significantly more abundant on rocky bottoms than on plain sand or mud bottoms beneath salmon farms (Rock: $3.2 \pm 0.8$ ind. $500 \mathrm{~m}^{-3}$; Sand/Mud: $\left.1.0 \pm 0.3 ; F_{1,160}=10.3, \mathrm{p}=0.002\right)$. Both Pollachius virens (Rock: $27.4 \pm 11.5$; Sand/Mud: $\left.13.8 \pm 4.1 ; F_{1,160}=1.8, \mathrm{p}=0.18\right)$ and $M e-$ lanogrammus aeglefinus (Rock: $2.6 \pm 1.4$; Sand/Mud: $1.2 \pm 0.4 ; F_{1,160}=1.4, \mathrm{p}=0.23$ ) were approximately twice as abundant on rocky bottoms as on sand or mud, but this did not translate into significant differences due to the high variability among counts.

Total farm-aggregated biomasses for Pollachius virens and Melanogrammus aeglefinus were not significantly correlated with farm area, farm depth or salmon biomass ( $p>0.07$ in all cases). Gadus morhua biomass was significantly related to average farm depth $\left(F_{1,7}=5.6, \mathrm{p}=0.04\right)$, with shallow farms aggregating greater biomasses than deeper farms. No significant relationships were found between G. morhua biomass and the attractive farm area or salmon biomass ( $p>0.10$ in both cases).

\section{DISCUSSION}

\section{Wild fish assemblages at farm and control locations}

Wild fish assemblages at salmon farms were consistently different to those at natural control locations in all 3 salmon farming regions investigated. This difference was due to higher abundances of Pollachius virens, Gadus morhua, Melanogrammus aeglefinus and Scomber scombrus at farms compared to controls, rather than differences in the species present at farm and control sites, indicating that farms attracted and concentrated fish from surrounding habitats. If our conservative estimates of total farm-aggregated biomasses of $10.2 \mathrm{t} \mathrm{farm}^{-1}$ (Fig. 6) hold across the geographical range of salmon farming in gated biomass at 7 of the 9 farms (Fig. 6a). In the Ryfylke region, $S$. scombrus were responsible for the majority of aggregated biomass at Farm 2 (55\%) and Farm 3 (99\%; Fig. 6d), while G. morhua and $M$. aeglefinus contributed most to total aggregated biomass at Farms 4, 5 and 7 (Fig. 6b,c).
Norway $\left(58^{\circ} \mathrm{N}\right.$ to $\left.71^{\circ} \mathrm{N}\right)$, they indicate that the 1198 active salmon farms in Norway in 2007 (Norwegian Fisheries Directorate 2008) as a whole aggregated over $12200 \mathrm{t}$ of wild fish on any given day during summer. Moreover, our average attractive farm area of 0.63 ha (Table 1) indicates that this amount of fish would be 


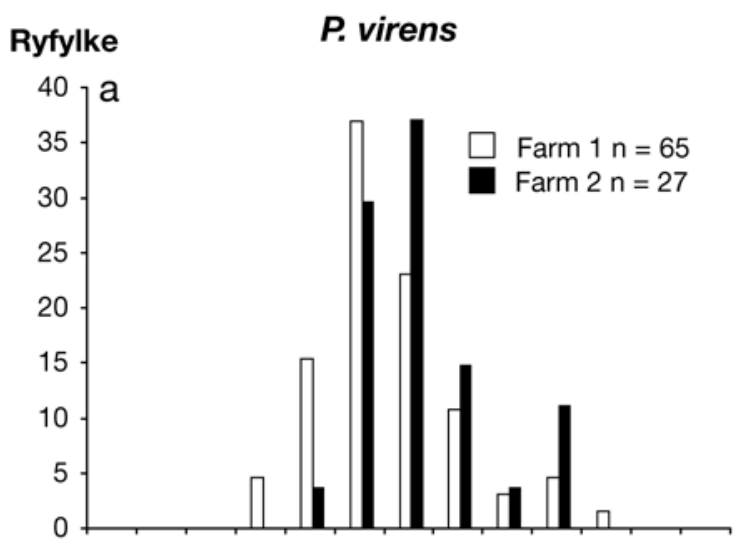

\section{G. morhua}
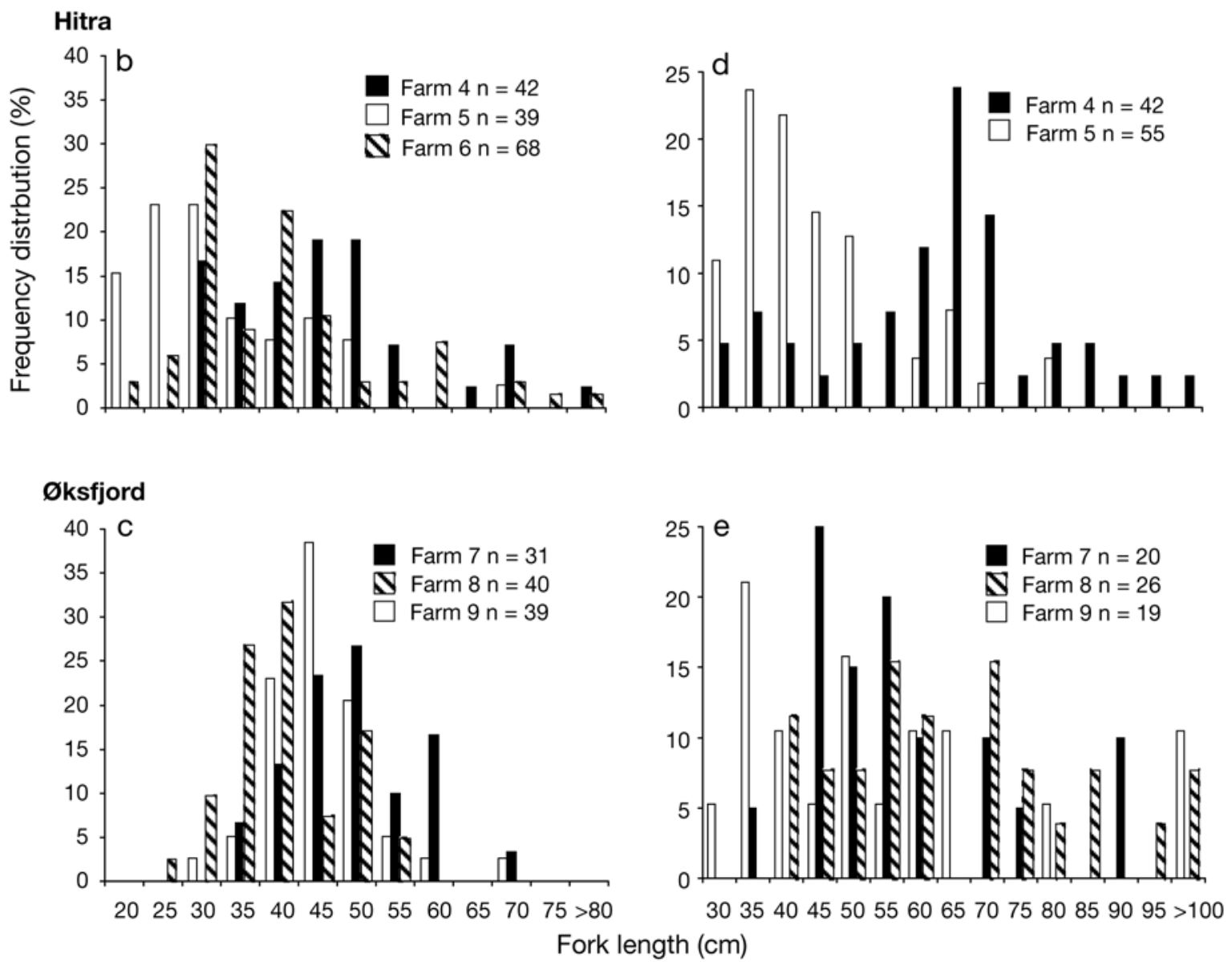

Fig. 5. Pollachius virens and Gadus morhua. Size frequency distributions of individuals aggregated at salmon farms in the 3 intensive fish farming regions

concentrated in a total of approximately 750 ha of coastal space. While schools of pelagic fish occur in natural locations at specific times (e.g. Bogetveit et al. 2008), the schooling of wild fish around farms and the temporal persistence of these aggregations demonstrates the highly attractive nature of this habitat to wild fish. The substantial, concentrated aggregations at salmon farms represents a re-distribution of wild fish in fjord and coastal waters and a substantial effect upon wild fish at an ecosystem scale as a direct consequence of sea-based aquaculture. Our estimates are applicable only for summer; substantial seasonal variability in aggregations has been documented around Mediterranean fish farms (Fernandez-Jover et al. 2008) and similar seasonal variability in assemblages may be expected around cold temperate salmon farms. 


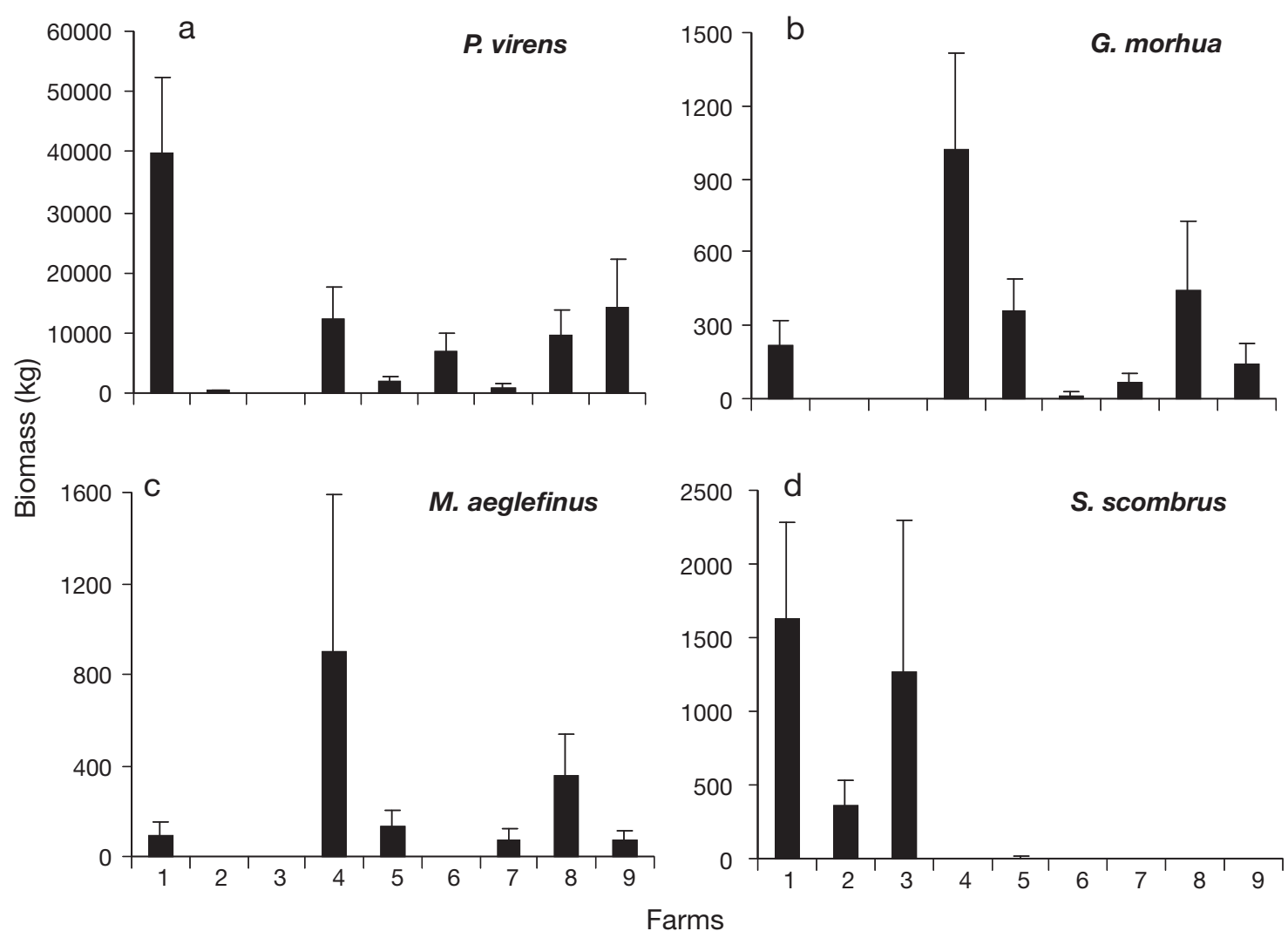

Fig. 6. Pollachius virens, Gadus morhua, Melanogrammus aeglefinus and Scomber scombrus. Estimates of the aggregated biomass $(+\mathrm{SE})$ of the 4 dominant species of wild fish within the attractive volume of each salmon farm. Ryfylke: Farms 1-3; Hitra: 4-6; Øksfjord: 7-9

Gadids dominated farm-associated assemblages in both number and biomass (Pollachius virens, Gadus morhua and Melanogrammus aeglefinus), while Scomber scombrus were common in surface waters around farms in southern Norway. Total farm-associated abundances were 5 to 10 times less than those estimated around sea bream and sea bass farms in Mediterranean Spain (Dempster et al. 2002, 2004), but total farm-associated biomasses spanned a similar range, as the average weight of fish was 5 to 10 times greater than the typically small, pelagic planktivores that associate with Mediterranean fish farms in greatest numbers (Dempster et al. 2002). Aggregation of wild fish at fish farms is therefore an effect of similar magnitude and ecological importance in cold- and warm-water farming environments.

\section{Abundance and biomass estimates from video counts}

Video counts likely under-estimated the overall abundances of fish present at farms. Capture data revealed that, while certain species were present at farms, they were not observed in the video counts. Further, Scomber scombrus in the Ryfylke region were likely under- estimated as we consistently observed large schools of thousands of individuals within the top $50 \mathrm{~cm}$ of the water column and within metres of the cages; camera counts conducted at $5 \mathrm{~m}$ depth did not observe these aggregations. In addition, the total farm-associated wild fish biomass estimates per farm (Fig. 6) were limited to the waters immediately adjacent to and directly beneath cages. The estimates assume that fish outside this limited area are not farm-associated, which is unlikely to be the case for mobile pelagic species such as Pollachius virens and S. scombrus. Ultrasonic tagging and tracking of farm-associated $P$. virens in Øksfjord revealed that $P$. virens may be resident at farms for weeks to months or may move among different farms and natural locations several kilometers apart (Uglem et al. 2009), thus using farms as frequently visited locations within a wider home range. If $P$. virens regularly move in and out of the attractive area of farms, this process would mask the true numbers of $P$. virens that regularly interact with farms, which are likely to be higher than our estimates restricted to the area of the cages. Nonetheless, our estimates are informative of the magnitude of aggregations in the immediate vicinity of the farms and can be used to better understand how wild fish and aquaculture interact in coastal waters. 


\section{Spatial and temporal variability of wild fish aggregations at Norwegian salmon farms}

While wild fish abundances varied among times at most farms, the relatively stable assemblage structure at farms among times (Fig. $2 \mathrm{~b}$ ) and the generally high numbers of aggregated fish indicate that salmon farms were persistently important habitats for wild fish throughout summer. The predominant depth-related patterns of wild fish around farms were related to the typical habitats of the largely bottom-dwelling species Gadus morhua and Melanogrammus aeglefinus, the pelagic species Scomber scombrus, and the benthopelagic behaviour of Pollachius virens, which were abundant in all 5 depth strata depending on the farm and sampling time.

Physical and biological factors intrinsic to each farm location may explain some of the variability, both in abundances and sizes of fish, observed in assemblages among farms. Temperature varied little among the 3 farms within each of the 3 farming regions, thus it is unlikely that temperature contributed to the observed differences for Pollachius virens, Gadus morhua and Melanogrammus aeglefinus. On a biogeographical scale, the greater prevalence of Scomber scombrus at Ryfylke $\left(59^{\circ} \mathrm{N}\right)$ than at Hitra $\left(63^{\circ} \mathrm{N}\right)$, and their absence from Øksfjord $\left(70^{\circ} \mathrm{N}\right)$, appears to be largely related to the northern limitations of their range (ICES 2008).

None of the farm habitat variables tested (attractive farm area, farm depth, or salmon biomass) explained the variability observed in Pollachius virens, Melanogrammus aeglefinus and Scomber scombrus abundances among farms, suggesting that other factors were important in creating location-related differences. Waste feed is known to be the major source of attraction to farms (Tuya et al. 2006). While we did not measure feed loss, it is possible that farms with higher levels of loss may have attracted more fish. However, farms with smaller salmon biomasses, where overall feed losses should have been lower, nevertheless attracted large abundances of wild fish (e.g. Farm 4, Table 1 \& Fig. 6). An alternate explanation for the variability observed may be that specific farms were located in closer proximity to important wild fish migration routes or suitable natural feeding habitats and thus had a greater pool of fish, or cohorts of different sizes of fish, to attract from nearby. In contrast to the other species, Gadus morhua abundances were positively correlated with shallow farms and rocky bottoms beneath farms, indicating that these variables may prove useful as predictive management tools of the likely importance of specific farming sites to wild G. morhua populations.

\section{Implications for waste dispersal from salmon farms}

Wild fish appear to play a far greater role in assimilating nutrient wastes from salmon farms than previously assumed, which is consistent with recent studies of this phenomenon for sea bream and sea bass farms in the Mediterranean Sea (Vita et al. 2004, Dempster et al. 2005, Fernandez-Jover et al. 2007b). Pollachius virens rely on waste feed for over $70 \%$ of their diet while in the vicinity of farms, while Gadus morhua, Melanogrammus aeglefinus and Scomber scombrus also consume lost pellets around farms (T. Dempster et al. unpubl. data). Farm-associated $P$. virens caught in summer $2007(\mathrm{n}=350)$ at the same 9 farms investigated here had an average of $14.2 \mathrm{~g}$ of waste pellets in their stomachs (T. Dempster et al. unpubl. data). An aggregation size of $10000 \mathrm{P}$. virens, which is within the range observed at 5 of 9 farms in the present study, would therefore equate to $142 \mathrm{~kg}$ of pellets consumed each day during summer, totaling $12.8 \mathrm{t}$ of waste food consumed over a 3 mo period. For a farm with $1000 \mathrm{t}$ of salmon that feeds at a rate of $1 \%$ of biomass (or $10 \mathrm{t}$ ) per day, $142 \mathrm{~kg}$ represents a minimum food loss of $1.4 \%$. These estimates illustrate the capacity wild $P$. virens schools have in reducing particulate sedimentation around salmon farms, thus providing an 'ecosystem service' to fish farmers. Models to predict sedimentation and nutrient dispersal around salmon farms do not account for this process, principally due to a lack of information to date. Our results suggest that models may overestimate sedimentation of food pellets at farms by tens of tons per year. Incorporating the effects of wild fish into models will resolve this inaccuracy.

\section{Potential for wild fish to act as disease vectors}

Wild fish have long been suspected to act as a pool of infection for various pathogens of cultured fish (Bricknell et al. 2006). Our results suggest that, along the Norwegian coastline, Pollachius virens, Gadus morhua, Melanogrammus aeglefinus and Scomber scombrus are candidates to act as vectors of pathogens and parasites among salmon farms throughout summer, as they occur in high abundances in the very close vicinity of numerous farms. P. virens, G. morhua and $S$. scombrus in particular were observed next to the cage walls and were therefore often within 1 to $2 \mathrm{~m}$ of the caged salmon. The most abundant farm-associated species, $P$. virens, may act as a natural reservoir of the salmonid alphavirus (SAV; Graham et al. 2006) and carries infectious pancreatic necrosis virus (IPNV), though at relatively low prevalence $(1.1 \%$; Wallace et al. 2008). If pathogens or parasites are shared and 
transmitted among salmon and these 4 species, residence at specific farms followed by movements to adjacent farms may contribute to the propagation of outbreaks, in an analogous way to the dispersal of bird flu to domestic birds by migrating wild birds (Chen et al. 2005). Further testing of this hypothesis by investigating the connectivity of salmon farming locations through wild fish movements is required.

\section{Interactions between wild fish, fisheries and aquaculture}

Ecological traps occur where animals preferentially select a habitat in which they do poorly relative to other available habitats (Robertson \& Hutto 2006). Ecological traps may form when artificial habitats that have the ecological cues that wild animals recognise in preferred habitats are introduced into natural settings (Battin 2004, Hallier \& Gaertner 2008). Typically, the existence of an ecological trap has been thought of as requiring negative behavioural or physiological effects that reduce the survival or reproductive capacity of a population (Battin 2004, Robertson \& Hutto 2006). However, even in the absence of any direct negative physiological or reproductive effects due to the close association of wild fish with salmon farms, the continuous concentration of wild fish around farms increases their vulnerability to capture and thus creates circumstances for the formation of an ecological trap if fishing interacts heavily with aquaculture sites. Population decline would likely be concealed under such circumstances, as catch per unit effort would remain high and confound traditional population estimates based on fisheries-dependent data.

At present, both commercial and recreational fishing in the near vicinity $(100 \mathrm{~m})$ of fish farms in Norway is prohibited to avoid fishing gear damaging farms. Fishing in areas immediately adjacent to farms (>100 m) occurs (Maurstad et al. 2007); however, the importance of this activity to overall catches is unknown. Numerous fjord areas in Norway have depressed Gadus morhua populations due to historically high fishing pressure; ICES has recommended zero catch of this stock since 2004 (Berg 2008). In fjords with intensive salmon farming where wild G. morhua stock levels are in decline, our results suggest that aggregations around fish farms may be important in the context of overall populations, and wider restrictions on bottomfishing gear in the near vicinity of farms may be particularly relevant. Thus managed, fish farming areas may offer an opportunity to protect a proportion of the $G$. morhua stock, so that farms act as a population source rather than an ecological trap. In contrast, fishing for Pollachius virens, which is not overfished at present, could co-exist in the vicinity of salmon farms within a management framework that restricts total catch levels, such as a total allowable catch, although the aggregating nature of fish farming habitats would have to be integrated into models for estimating stocks.

Acknowledgements. Lorena Gallart Jornet and Johanna Järnegren are thanked for their assistance during the fieldwork. Funding was provided by the Norwegian Research Council Havet og kysten program to the CoastACE project (no. 173384).

\section{LITERATURE CITED}

Battin J (2004) When good animals love bad habitats: ecological traps and the conservation of animal populations. Conserv Biol 18:1482-1491

Berg E (2008) Norwegian coastal cod still in decline. Kyst og Havbruk 2:79-81 (in Norwegian)

> Bogetveit FR, Slotte A, Johannessen A (2008) The ability of gadoids to take advantage of a short-term high availability of forage fish: the example of spawning aggregations in Barents Sea capelin. J Fish Biol 72:1427-1449

> Bricknell IR, Bron JE, Bowden TJ (2006) Diseases of gadoid fish in cultivation: a review. ICES J Mar Sci 63:253-266

> Carss DN (1990) Concentrations of wild and escaped fishes immediately adjacent to fish farm cages. Aquaculture 90: $29-40$

Chen H, Smith GJD, Zhang SY, Qin K and others (2005) H5N1 virus outbreak in migratory waterfowl. Nature 436: 191-192

deBruyn AMH, Trudel M, Eyding N, Harding J and others (2006) Ecosystemic effects of salmon farming increase mercury contamination in wild fish. Environ Sci Technol 40:3489-3493

> Dempster T, Sanchez-Jerez P, Bayle-Sempere JT, GiminezCasualdero F, Valle C (2002) Attraction of wild fish to seacage fish farms in the south-western Mediterranean Sea: spatial and short-term variability. Mar Ecol Prog Ser 242: $237-252$

Dempster T, Sanchez-Jerez P, Bayle-Sempere JT, Kingsford MJ (2004) Extensive aggregations of wild fish at coastal sea-cage fish farms. Hydrobiologia 525:245-248

> Dempster T, Fernandez-Jover D, Sanchez-Jerez P, Tuya F, Bayle-Sempere J, Boyra A, Haroun RJ (2005) Vertical variability of wild fish assemblages around sea-cage fish farms: implications for management. Mar Ecol Prog Ser 304:15-29

> Dempster T, Sanchez-Jerez P, Tuya F, Fernandez-Jover D, Bayle-Sempere J, Boyra A, Haroun R (2006) Coastal aquaculture and conservation can work together. Mar Ecol Prog Ser 314:309-310

Diamant A, Colonri A, Ucko M (2007) Parasite and disease transfer between cultured and wild coastal marine fish. CIESM Workshop Monograph 32:49-54. Available at www.ciesm.org/online/monographs/Lisboa.html

FAO (Food and Agriculture Organization of the United Nations) (2008) Fishstat Plus. Aquaculture production: quantities 1950-2007. FAO, Rome

Fernandez-Jover D, Lopez-Jimenez JA, Sanchez-Jerez P, Bayle-Sempere J, Gimenez-Casalduero F, MartinezLopez FJ, Dempster T (2007a) Changes in body condition and fatty acid composition of wild Mediterranean horse mackerel (Trachurus mediterraneus, Steindachner, 1868) 
associated to sea-cage fish farms. Mar Environ Res 63: $1-18$

Fernandez-Jover D, Sanchez-Jerez P, Bayle-Sempere J, Carratala A, Leon VM (2007b) Addition of dissolved nitrogen and dissolved organic carbon from wild fish faeces and food around Mediterranean fish farms: implications for waste-dispersal models. J Exp Mar Biol Ecol 340:160-168

Fernandez-Jover D, Sanchez-Jerez P, Bayle-Sempere J, Valle C, Dempster T (2008) Seasonal patterns and diets of wild fish assemblages associated to Mediterranean coastal fish farms. ICES J Mar Sci 65:1153-1160

Graham DA, Jewhurst H, McLoughlin MF, Sourd P, Rowley HM, Taylor C, Todd D (2006) Sub-clinical infection of farmed Atlantic salmon Salmo salar with salmonid alphavirus - a prospective longitudinal study. Dis Aquat Org 72:193-199

Hallier JP, Gaertner D (2008) Drifting fish aggregation devices could act as an ecological trap for tropical tuna species. Mar Ecol Prog Ser 353:255-264

Harmelin-Vivien M (1985) Evaluation visuelle des peuplements et populations de poissons. Methodes et problemes. Rev Ecol 40:467-539 (in French)

- Heagney EC, Lynch TP, Babcock RC, Suthers IM (2007) Pelagic fish assemblages assessed using mid-water baited video: standardising fish counts using bait plume size. Mar Ecol Prog Ser 350:255-266

ICES (2008) ICES Fish-Map. Mackerel (Scomber scombrus). www.ices.dk/marineworld/fishmap/ices/pdf/mackerel.pdf

Maurstad A, Dale T, Bjørn PA (2007) You wouldn't spawn in a septic tank, would you? Hum Ecol 35:601-610

Norwegian Fisheries Directorate (2008) Statistics for Aqua-

Editorial responsibility: Hans Heinrich Janssen,

Oldendorf/Luhe, Germany culture 2007. www.fiskeridir.no/fiskeridir/kystsone_og_ havbruk/statistikk

Robertson BA, Hutto RL (2006) A framework for understanding ecological traps and an evaluation of existing evidence. Ecology 87:1075-1085

Tuya F, Sanchez-Jerez P, Dempster T, Boyra A, Haroun R (2006) Changes in demersal wild fish aggregations beneath a sea-cage fish farm after the cessation of farming. J Fish Biol 69:682-697

Uglem I, Bjørn PA, Dale T, Kerwath S and others (2008) Movements and spatiotemporal distribution of escaped farmed and local wild Atlantic cod (Gadus morhua L.). Aqua Res 39:158-170

Uglem I, Dempster T, Bjørn PA, Sanchez-Jerez P, Økland F (2009) High connectivity of salmon farms revealed by aggregation, residence and repeated movements of wild fish among farms. Mar Ecol Prog Ser 384:251-260

Underwood AJ (1997) Experiments in ecology: their logical design and interpretation using analysis of variance. Cambridge University Press, Cambridge

- Vita R, Marin A, Madrid JA, Jimenez-Brinquis B, Cesar A, Marin-Guirao L (2004) Effects of wild fishes on waste exportation from a Mediterranean fish farm. Mar Ecol Prog Ser 277:253-261

> Wallace IS, Gregory A, Murray AG, Munro ES, Raynard RS (2008) Distribution of infectious pancreatic necrosis virus (IPNV) in wild marine fish from Scottish waters with respect to clinically infected aquaculture sites producing Atlantic salmon, Salmo salar L. J Fish Dis 31:177-186

Weir LK, Grant JWA (2005) Effects of aquaculture on wild fish populations: a synthesis of data. Environ Rev 13:145-168

Submitted: January 29, 2009; Accepted: April 4, 2009 Proofs received from author(s): May 15, 2009 